\title{
From school to where? How social class, skills, aspirations, and resilience explain unsuccessful school-to-work transitions
}

Citation for published version (APA):

Dicks, A., Levels, M., \& van der Velden, R. (2020). From school to where? How social class, skills, aspirations, and resilience explain unsuccessful school-to-work transitions. Maastricht University, Graduate School of Business and Economics. GSBE Research Memoranda No. 013 https://doi.org/10.26481/umagsb.2020013

Document status and date:

Published: 24/04/2020

DOI:

10.26481/umagsb.2020013

Document Version:

Publisher's PDF, also known as Version of record

Please check the document version of this publication:

- A submitted manuscript is the version of the article upon submission and before peer-review. There can be important differences between the submitted version and the official published version of record. People interested in the research are advised to contact the author for the final version of the publication, or visit the DOI to the publisher's website.

- The final author version and the galley proof are versions of the publication after peer review.

- The final published version features the final layout of the paper including the volume, issue and page numbers.

Link to publication

\footnotetext{
General rights rights.

- You may freely distribute the URL identifying the publication in the public portal. please follow below link for the End User Agreement:

www.umlib.nl/taverne-license

Take down policy

If you believe that this document breaches copyright please contact us at:

repository@maastrichtuniversity.nl

providing details and we will investigate your claim.
}

Copyright and moral rights for the publications made accessible in the public portal are retained by the authors and/or other copyright owners and it is a condition of accessing publications that users recognise and abide by the legal requirements associated with these

- Users may download and print one copy of any publication from the public portal for the purpose of private study or research.

- You may not further distribute the material or use it for any profit-making activity or commercial gain

If the publication is distributed under the terms of Article 25fa of the Dutch Copyright Act, indicated by the "Taverne" license above, 
Alexander Dicks, Mark Levels,

Rolf van der Velden

From school to where? How social class, skills, aspirations and resilience explain unsuccessful school-to-work transitions

RM/20/013

\section{GSBE}

Maastricht University School of Business and Economics 


\title{
From School to Where? How Social Class, Skills, Aspirations, and Resilience Explain Unsuccessful School-to-Work Transitions
}

\author{
Alexander Dicks (Research Centre for Education and the Labor Market, Maastricht \\ University) \\ Mark Levels (Research Centre for Education and the Labor Market, Maastricht University) \\ Rolf van der Velden (Research Centre for Education and the Labor Market, Maastricht \\ University) \\ Corresponding author: \\ Alexander Dicks \\ Tongersestraat 53, 6211LM Maastricht \\ a.dicks@,maastrichtuniversity.nl
}

\begin{abstract}
The school-to-work transition is one of the formative phases in the life course. During it, many important decisions are made. We use sequence analysis and logistic regression to study why some young people become NEET (Not in Employment, Education, or Training). We find that classical stratification variables such as higher parental education and higher education increase the probabilities for a successful school-to-work transition. In addition, we hypothesized that alignment of educational attainment and occupational aspirations as well as personality should play a role in this process. While we do not find evidence for an additional effect of alignment, we do find one for resilient personality. We also test hypotheses of mediation and moderation. We find that there is significant mediation of social class via youth's education, but not via aspirational alignment or personality. We also find that education and personality can partly compensate for a low social class background.
\end{abstract}

Keywords: NEET; school-to-work transition; sequence analysis; personality; aspirations

\section{Acknowledgement:}

We thank Per Bles and Davey Poulissen for their valuable comments and Hans Heijke and Esther Soudant for their assistance and organization of the series. We also thank the anonymous reviewers and editors of the special issue Wendy Smits and Anet Weterings for comments on an earlier version of this manuscript which has been published in Tijdschrift voor Aarbeidsvraagstukken 34(4). 


\section{Introduction}

A lot is at stake for youth during the school-to-work transition. They are required to "construct their own life course through the choices and actions they take within the opportunities and constraints of history and social circumstances" (Elder, Johnson, and Crosnoe 2003; Shanahan 2000). Yet, some youth do not succeed in making this transition. A disrupted school-to-work transition has important negative consequences for later life outcomes, including but not limited to wage scars, low re-entry rates, and well-being (Bell and Blanchflower 2011; Bynner and Parsons 2002; Gregg and Tominey 2005; Luijkx and Wolbers 2009; Oreopoulos 2007). Understanding why some youth fail is paramount for designing policies to prevent this. In this paper, we investigate how social class, personality, and occupational aspirations predict an unsuccessful school-to-work transition in the Netherlands. As far as we know, we are the first to study those in concert while at the same time having high quality register data about the complete school-to-work transition until age 30. We aim to explain why some young people experience a school-to-work transition that is characterized by recurrent, significant periods in which they were Not in Employment, Education, or Training (so-called NEET).

The risk of becoming NEET is often associated with variables that are key in status attainment models: skills, education, and social class. Human capital explanations relate the probability of finding employment to the skills that are demanded on the labor market. As such, young people with low educational attainment, or no degree at all, would struggle on the labor market (Bynner and Parsons 2002; McVicar and Anyadike-Danes 2002; Shavit and Müller 1998; van der Velden and Wolbers 2006). The role of parental background for the school-to-work transition is also well-established and children from higher social backgrounds are better able to make the school-to-work transition (Bynner and Parsons 2002; Caspi et al. 1998; Coles et al. 2002; Furlong and Biggart 1999; Sewell, Haller, and Portes 1969; Staff and Mortimer 2008; Thompson 2011). However, human capital and social class may not be the only factors that explain unsuccessful transitions. 
One important other factor might be aspirations. Occupational aspirations are considered a major force in youths' occupational development (Schoon and Parsons 2002). Not having clearly defined aspirations on the other hand can be detrimental for labour market integration (Holtmann, Menze, and Solga 2017; Sabates, Harris, and Staff 2011; Staff et al. 2010; Vuolo, Staff, and Mortimer 2012; Yates et al. 2011). Despite this, many young people do not have a clear picture of what they want to become. Some do not know which occupation to pursue (Sabates et al. 2011; Staff et al. 2010; Yates et al. 2011). Others refuse to make choices or do not want to commit to them (Du Bois-Reymond 1998). Secondly, unrealistic aspirations do not aid labor market integration either. Some youth aspire to an occupation that does not align with their educational qualifications and expectations (Croll 2008; Sabates et al. 2011), and set the bar too high, or too low.

Another factor that we will investigate is personality. The extent to which people are able to make a successful school-to-work transition, that is, to graduate from education and to find and hold employment, is likely related to personality. Many studies have shown the importance of personality and other non-cognitive skills on the labor market (Borghans et al. 2008; Gelissen and de Graaf 2006; Heckman, Stixrud, and Urzua 2006; Jencks 1979; Roberts et al. 2007; Uysal and Pohlmeier 2011). In this context, personality traits are usually interpreted as non-cognitive skills that are rewarded on the labor market (Bowles, Gintis, and Osborne 2001). However, in the context of NEET, the extent to which people are resilient enough to overcome setbacks and are able to adapt to new situations might be more elementary for succeeding in the successful school-to-work transition (Ng-Knight and Schoon 2017; Nieuwenhuis et al. 2016; Pinquart, Juang, and Silbereisen 2003).

While human capital, social class, aspirations, and personality are all important factors in shaping the school-to-work transition, research exploring their role has largely developed along separate lines (Damian et al. 2015). This is problematic, as the four factors are intricately wound up. The following three examples lay out this issue. Firstly, the development of career identitie s 
and - by extension - unclear aspirations are mediators of a psychological process shaped by people's personality (Burns et al. 2013; Germeijs and Verschueren 2011; Guay et al. 2003; Hirschi 2012; Martincin and Stead 2014; Tokar, Fischer, and Subich 1998). Second, parents of higher social class might know better than parents of lower social class which personality traits are rewarded by the school system and the labor market and foster such skills in their children (Bowles et al. 2001; Farkas 2003; Shanahan et al. 2014). Third, social class is also mediated through education and cognitive skills. Assuming that all parents want their children to at least maintain their social class, parents from higher social classes have to make sure their children attend the highest school tracks. In addition, they likely have access to better information about the school system, partly due to their own experience (Pfeffer 2008). Cultural and social capital are likely playing a role as well (Boudon 1974; Bourdieu and Passeron 1977; Coleman 1988; Erikson et al. 2005; Lareau 2000).

To better understand how personality and aspirations shape the school-to-work transition, we study their effects in conjunction. We address the following research question: to what extent and how do human capital, social class, personality, and aspirations predict a school-to-work trajectory that is predominantly characterized by time spent in NEET?

We combine high-quality administrative data from the Social Statistical Database (SSD) of Statistics Netherlands (CBS) (Bakker, van Rooijen, and van Toor 2014) with the 1999 Secondary Education Student Cohort survey (VOCL'99) (Kuyper, Lubbers, and Van der Werf 2003). The VOCL'99 provides us with measures of aspirations and a five-factor personality inventory (Hendriks, Hofstee, and De Raad 1999). We analyze these data in two steps. First, we use sequence analysis to explore different school leaving trajectories into and out of work, education, and NEET. Sequence analysis is especially suited for this task because it does not assume a data generating process and does not underrepresent irregular careers (Aisenbrey and Fasang 2010). Register data are especially useful to study small groups and phenomena of low incidence and are optimal for sequence analysis because they offer detailed longitudinal data 
without recall bias or panel attrition (Bäckman and Nilsson 2016; Bakker et al. 2014). Secondly, we use multinomial regression to our hypotheses about unsuccessful school-to-work transitions.

Our research is first and foremost informative about the way in which unsuccessful pathways from school to work should be understood. One of the main problems of the NEET definition is that it lumps together various groups of people, who may be inactive on the labor market for very different reasons. Reasons for becoming NEET are widely diverse, and not all NEET may be vulnerable. Clearly, lumping together different groups of youth under an umbrella term obscures important differences (Furlong 2006; Maguire 2015; Yates and Payne 2007): backpackers taking a gap year differ fundamentally from youth who are inactive because their skills are not demanded on the labor market. Efforts to uncover the diversity of NEETs mostly focused on identifying different predictors of NEET as a state (Eurofound 2016). However, studying NEET at a single point in time does not help to uncover the diversity of this group. One needs to take a life course perspective and study trajectories.

As indicated above, this paper uses a unique combination of survey data and register data, allowing us to have detailed information on these trajectories. The availability of such data in the Netherlands offers a strong comparative advantage to properly test hypotheses about the school-to-work transition, but there is also a substantial reason for focusing on the Dutch case. The NEET rate in the Netherlands is the lowest in the European Union (Eurofound 2012). Hence, NEETs might be especially negatively selected and vulnerable. In no other European country does disability account for economic inactivity to the extent it does in the Netherlands (Eurofound 2016). Given that Dutch NEETs are relatively irresponsive to active labor market policies (Cammeraat, Jongen, and Koning 2017), it seems unlikely that the standard human capital explanation alone can explain their NEET status. Additional explanations have to be explored. On the other hand, in no other European country are NEETs at a lower risk from social exclusion (Eurofound 2016). We should thus expect considerable heterogeneity in 
school-to-work transitions which we aim to explain. It is to these explanations that we turn in the next section.

\section{Theory and hypotheses}

The school-to-work transition is a transformative rite of passage, marking school-leavers' transition from being predominantly in education to being predominantly active on the labor market. However, this is only reality for a limited number of people. For many, the school-towork transition is not so much a transition as well as a trajectory (Brzinsky-Fay 2014) or pathway (Shanahan 2000). Rather than experiencing a single event which marks the end of school and the beginning working life, they experience a much messier transitory phase of switching back and forth between various states (Kerckhoff 2003). Some might find short-term jobs right out of school but lose them quickly and become NEET for some time until they find a more stable job. Some might experience frictional unemployment and might go back to school to earn additional qualifications. Some might find a short-term job and then go back to school. Some might remain in education well into their late twenties while others become long-term NEET or experience a volatile pathway that is predominated by frequently recurrent spells as NEET. It is these unsuccessful and likely volatile school-to-work transitions that interest us here, and in the remainder of this section, we will derive hypotheses from various theories to explain these trajectories. Given the demonstrated scarring-effects of problematic school-towork transitions (Gregg and Tominey 2005; Schmillen and Umkehrer 2013; Steijn, Need, and Gesthuizen 2006), we interpret a school-to-work transition characterized by frequent and significant spells of NEET as problematic.

So, what explains NEET? The concept was mostly defined and developed by policymakers and lumps together young people that are NEET for widely different reasons (Furlong 2006; Maguire 2015; Yates and Payne 2007). Not only has the term as such been criticized, but also the literature on NEET is generally relatively light on theoretical explanations. We argue that we need to unpack NEET before we can explain it. For instance, NEET is very much related to 
early-school leaving, youth unemployment, and the school-to-work-transition in general. All of which have been studied extensively. We can draw on this rich literature and their theories to further our knowledge of NEETs.

\subsection{Social class}

Social class background has long been shown to influence labor market success and related outcomes of the status attainment process. Most theories describe social class as the underlying cause of other inequalities which then translate to inequalities in labor market outcomes. First, via education, because children from higher social backgrounds fare better in education and make different educational choices than their lower-class peers (Boudon 1974; Bourdieu and Passeron 1977; Erikson et al. 2005). Second, because they have higher and better aligned aspirations or at least can make up for a lack of orientation (Croll 2008). Third, because they have more cultural (Bourdieu and Passeron 1977) as well as social capital (Coleman 1988; Lin 2001; van Tubergen and Volker 2014; Verhaeghe, Li, and Van de Putte 2013). Fourth, because parents foster specific personality traits in their children (Farkas 2003). All these resources help young people to achieve educationally and to find employment. We thus expect a total effect of social class:

The higher the socioeconomic origin class of youth, the lower the likelihood that they experience a trajectory predominated by NEET spells (Hypothesis 1).

\subsection{Human capital}

Widely recognized are the effects of educational credentials and skills, i.e. human capital, on the labor market. Employers seek out the most qualified employees in an intricate matching process (Logan 1996). Hence, education is an investment which is rewarded on the labor market (Becker 1964). Because ability is usually unobserved, educational degrees also act as informative proxy measures of ability (Spence 1973). Indeed, low achieving school leavers face great difficulties in successfully entering the labor market (Bynner and Parsons 2002; McVicar 
and Anyadike-Danes 2002; Shavit and Müller 1998; van der Velden and Wolbers 2006). We thus expect that:

Youth from higher secondary-education tracks have a lower likelihood that they experience a trajectory predominated by NEET spells than youth from secondaryeducation tracks (Hypothesis 2a).

As well as:

The higher the cognitive abilities of youth, the lower the likelihood that they experience a trajectory predominated by NEET spells (Hypothesis 2b).

\subsection{Aspirations}

Stratified, occupationally specific education systems like the Dutch system allocate young people to the labor market in two ways: by sorting them into tracks, and by providing them with the right skills set to be productive in the early career stages. During their educational careers, pupils in such systems have to make a number of important decisions: what courses to take or drop, what skills set to focus on, and on what level. In making these decisions, these pupils are shaping their future, and preparing themselves for the transition to work. Children form aspirations through a process of 'circumscription and compromise', transmission their interests, social class, their subjective perception of opportunities, and gender (Gottfredson 1981).

Having clear aspirations early on in the educational career may guide pupils by helping them set an educational course that helps them realize their aspirations. Being uncertain about their aspirations may keep pupils from making sufficiently informed decisions, which in the end could lead to a much more volatile transition. Previous evidence suggests that uncertain aspirations increase the probability to attain lower levels of education (Sabates et al. 2011) to become NEET (Yates et al. 2011) and to earn lower wages (Sabates et al. 2011; Staff et al. 2010).

Therefore, we expect that: 
Youth with uncertain aspirations have a higher likelihood to experience a trajectory predominated by NEET spells (Hypothesis 3a).

Another aspect of aspirations is whether they are realistic. Youth who aspire to have a job for which they underestimate the education requirements, will most likely face issues during the school-to-work transition (Croll 2008; Sabates et al. 2011). For this reason, we expect that:

The better the occupational aspirations of youth align with their educational expectations, the lower the likelihood that they experience a trajectory predominated by NEET spells (Hypothesis 3b).

[Table 1: Aspirations about here]

\subsection{Personality}

The relation between personality and labor market outcomes has been researched widely (for reviews see Borghans et al. 2008; Farkas 2003; Roberts et al. 2007). In this literature, usually five separate traits of personality (e.g. neuroticism, extraversion, openness, agreeableness, and conscientiousness) are distinguished, and then linked to specific labor market outcomes. Although widely practiced, the conceptualization of personality as traits (variable-centered approach) has theoretical as well as empirical downsides.

While correlations of single personality traits and outcomes are well established, theoretically these links are not always clear-cut and invite post-hoc explanations. The variable-centered approach obfuscates that single personality traits do not exist in isolation. Personality traits are in fact approximations of personality which itself is a hierarchical system of subcomponents that interact within persons (Ferguson and Hull 2018; McCrae and Costa 1987). Hence, empirically, personality traits covary and account for shared variance therewith concealing mutual influences while interactions of five variables are difficult to model and interpret (Merz and Roesch 2011). Therefore, we use a conceptualization of typologies of personality traits 
which represent combinations of various personality traits within a person (person-centered approach), thereby approximating such interactions (Ferguson and Hull 2018; Lanza et al. 2010; Merz and Roesch 2011). The most common personality typologies distinguish "Resilient/Well-adjusted", "Undercontrolled", "Reserved" and "Overcontrolled/Excitable" types (Block and Block 1980; Ferguson and Hull 2018). Resilient/Well-adjusted individuals score positive (socially desirable) on all five personality traits (Asendorpf et al. 2001; Ferguson and Hull 2018; Robins et al. 1996). They do well in education (Robins et al. 1996), are welladjusted and can easily adapt to changing and uncertain environments (Akse et al. 2004; Asendorpf et al. 2001). Being resilient is thought to be a prime asset during the transition to adulthood, for example predicting earlier timing of transitions such as leaving the parental home (only for boys) and finding a part-time job (only for girls) (Dennissen, Asendorpf, and van Aken 2008). Because resilient youth are expected to be more able to cope with the uncertaintie s and stress during the school-to-work transition, we hypothesize that:

Resilient youth are less likely to experience a trajectory predominated by NEET spells (Hypothesis 4).

\subsection{Mediation}

As we argued before, all these factors likely act in concert. First, social class background is a key variable in the formation of children's personality (Farkas 2003). Second, parents are likely to guide their children in their occupational choices (Croll 2008). Third, and most straightforward, is the link from social class to labor market success via education (Boudon 1974; Bourdieu and Passeron 1977): children of higher educated parents perform better in school and their parents can assist them in other schooling related matters and decision making. Hence, we expect that:

The effect of social class is mediated by (a) young people's education, (b) young people's personality, and (c) the alignment of young people's occupational aspirations (Hypothesis 5). 


\subsection{Moderation}

Not only are education, personality, and aspirations mediators of social class, they could also compensate for the lack of resources that parents from a lower socioeconomic background can offer their children (Mirowsky and Ross 2003; Ng-Knight and Schoon 2017; Shanahan et al. 2014). If, say, a child from lower-class background has very clear goals about the future and is doing well in school, or is resilient against stress and setbacks, the negative effect of social class might become less negative. Hence, we expect that:

The effect of social class is moderated by (a) young people's education, (b) young people's personality, and (c) the alignment of young people's occupational aspirations. (Hypothesis 6).

\section{Data}

To test our hypotheses, we use a combination of register data and survey data. We use the VOCL'99 data collected from a random sample of pupils in the first year of secondary education in 1999 (Kuyper et al. 2003). Sampling was done on the school level. From 1144 school locations in the Netherlands, 246 were randomly selected. From these 246, 126 school locations agreed to participate. Within these 126 school locations, there were 825 first grade classes in which were 19,391 pupils. These represent about $11 \%$ of that school entry cohort (Van Berkel 1999). Data was collected from three sources: schools were asked to deliver background information on their pupils, pupils filled out questionnaires and ability tests and additional questionnaires were taken home by the pupils to be filled out by parents (in 147 cases by care takers). We link individuals from the VOCL'99 to the Social Statistical Database (SSD) (Bakker et al. 2014). The SSD provides information on the monthly activity of all persons registered in the Netherlands. We use these data to construct detailed education and employment biographies for all pupils. We can identify 19,291 of our original sample in the administrative data using the personal identifier variable supplied in the VOCL. We subsequently match and observe labor market and education trajectories for 19,284 individuals 
from January 2001 until December 2018. For the sequence analysis, we restrict the sample to those who have valid data for at least $90 \%$ of the episodes under observation $(\mathrm{N}=18,435)$. We then perform listwise deletion on our variables of interest so that our final analytical sample is $\mathrm{N}=10,955$. Some of the missing data stems from the parental questionnaire which unfortunately has sometimes not been filled in. However, we have to rely on the parental questionnaire for parental education because education was not yet properly measured in the administrative data for that cohort. Some missing data also stems from the personality items.

[Table 2 about here]

\section{Measurements}

We use the following variables in our analyses. Descriptive statistics of all variables are presented in Table 2 .

Monthly activity sequence: The monthly activity is obtained by merging two datasets from the Dutch administrative data (SSD) (Bakker et al. 2014). The dataset SECMBUS includes calendar data on the main economic activity (variable SECM) based on the main source of income. While it is theoretically possible to receive a larger income from social welfare than from employment in practice this is seldom the case and the employment would have to be low income/low workhours for this to happen. This variable has twelve states: (1) employee, (2) director/major share-holder, (3) self-employed, (4) other self-employed, (5) recipient of unemployment insurance, (6) recipient of welfare, (7) recipient of other social benefits, (8) recipient of illness and disability benefits, (9) recipient of pension, (10) (not yet) pupil/student with income, (11) (not yet) pupil/student without income, (12) other without income. We combine states 1-4 into 'Working', states 5-9 \& 12 into 'NEET', and states 1011 into 'Education'. The dataset STUDERENDEBUS includes calendar data on registration in publicly funded education (variable SOORTONDERWSTU). We combine the information from both datasets to distinguish secondary education from further education. We thus merge the two variables, whereas we let education overwrite other states. Primary 
education, practical education, and secondary education are grouped together as "Secondary Education and below". The other states represent the three main types of further education in the Netherlands, upper secondary vocational education (MBO), university of applied science (HBO), and research university (WO). Before 2004, there is less information available on the educational activity. That is especially the case for primary and special education as well as vocational training. In such cases, education attendance is assigned by Statistics Netherlands based on compulsory schooling age. From 2004 onwards, this is done less often. For our sample, that means that until the Age of 16 there might be some imputation but after that not anymore.

\section{$\underline{\text { Social Class }}$}

Parental education: in the VOCL parental questionnaire, parents were asked to name their own and their partner's highest obtained educational degree. The highest of either answer refers to the highest obtained parental education, measured in categories from primary education to tertiary education. We use a collapsed version of the variable, distinguishing primary, secondary, and tertiary education (Bachelor or above).

Parental joblessness history: in the VOCL parent questionnaire, parents were also asked to recall their own and their partner's employment history and to name the total duration spent without a job since the age of 15 . Answers ranged from no joblessness history to more than ten years. We sum up the values of both partners and distinguish between "Never jobless", "1 to 2 years", and "more than 2 years".

Parental household income: using the Social Statistical Database (Dataset INTEGRAAL HUISHOUDENS INKOMEN) we can link personal identifiers to households and have access to the yearly household income. We use the value from 2003 as it is the earliest available. Some observations have negative values which we replace with $1 €$.

Parental household homeownership: using the same dataset used for the household income, we have information on the homeownership status of the household in 2003. The original 
variable distinguishes owned housing from rented with subsidies and rented without subsidies. As the receival of subsidies mainly relies on income which we already measure, we dichotomize the variable into owned (0) and rented (1).

\section{$\underline{\text { Human Capital }}$}

Cognitive skills: the VOCL study let pupils take an "entry test" of cognitive abilities in three domains, math (Cronbach's $\alpha=.83$ ), language (Cronbach's $\alpha=.74$ ), and information processing (Cronbach's $\alpha=.79$ ) (Kuyper et al. 2003). Values were assigned by CBS for students who only finished two of the three subdomains (Kuyper et al. 2003). For 1216 students who did not finish any subdomain and for 36 students who only finished one subdomain, no test data is available. The total score is recorded as variable RCTOT. This "entry test" is analog to the CITO "end test" and both correlate highly, $r=.82, \mathrm{p}<.01$. The CITO "end test" is used for tracking students after primary school and hence both RCTOT and CITO score correlate highly with the tracking advice given $(r=.78, \mathrm{p}<.01 ; r=.82, \mathrm{p}$ $<.01)$. To aid interpretation we standardize the score of RCTOT to the sample mean after listwise deletion.

Last track enrolled: From the monthly activity variable described above, we take the educational track that the pupil was last enrolled in before leaving secondary school for the first time. Here, we also distinguish between general tracks giving access to higher education (HAVO and VWO) from vocational tracks (VMBO, coded as the reference category) as well as practical education. As described above, for some pupils, administrative data on the secondary school attendance was unavailable. There are cases of missing data on educational tracks prior to being first registered as in work, or NEET. There are also cases where Statistics Netherlands assumes pupils to be in school without additional info whether they really are (in case of missing data before the age of 16 in accordance with legal school age). Using the VOCL survey, we can alleviate these shortcomings to some degree. First, because we use the VOCL survey as our base sample, we are sure that at the time of the survey, all 
of the observed pupils were enrolled in secondary education in the Netherlands. Second, from the VOCL survey we know which track a pupil was enrolled and can use this to verify the origin of the imputations. The majority of assigned cases was enrolled in the vocational track (VMBO) in 1999 (see Appendix).

\section{$\underline{\text { Aspirations }}$}

Occupational aspirations: in the VOCL questionnaire, pupils responded to the question "Do you already know what you want to become later?" with Yes or No. If answered yes, they were asked to name the occupation. To classify the occupations listed by the pupils, we performed exact matching of answers to the ISCO classification using text responses from the publicly available conversion tools provided by Ganzeboom and Treiman (2012). For unmatched answers, we performed manual string manipulations, i.e. removing typos and symbols and/or matched answers manually to the ISCO classification of occupations. We classify occupational aspirations as professional (ISCO major groups 1 \& 2) or nonprofessional (ISCO major groups 3-10) as well as "Don't know" if the answer to the previous filter question was "No" or if the answer was "Yes" but no occupation was named by the pupil. We then combine the occupational aspiration with the educational expectation variable: students were asked to "imagine you are going to continue learning which education do you think you will follow?". Possible answers corresponded to the different tracks of the Dutch education system as well as "I don't know yet". Combining the two gives us a measurement of how well a pupil assesses whether the aspiration is achievable. Table 1 gives an overview of the different alignments.

\section{$\underline{\text { Personality }}$}

Resilience: Personality traits were assessed in February 2001 when participants were 14 years old. The Five Factor Personality Inventory (FFPI) (Hendriks et al. 1999) consists of 100 items to measure Extraversion, Agreeableness, Conscientiousness, Emotional Stability, and Autonomy. Responses were collected with a five-point scale ranging from 1 (not at all 
applicable) to 5 (entirely applicable). Data selection and cleaning relied on the standard FFPI scoring procedure (Hendriks et al. 1999): Students were excluded if less than $70 \%$ of items were answered, responses were corrected for positive answering bias (acquiescence; 'yeasaying'), and missing values were imputed by the student's personal mean on the answered items per factor pole. We define resilience as above average values on Emotional Stability, Conscientiousness, Agreeableness, Autonomy, and Extraversion.

\section{$\underline{\text { Control variables }}$}

Single parent: parents were asked to give information on their marital status. We distinguish single parent households (coded as 1) from two parent households (coded as 0). We also added a category indicating whether the parental questionnaire was filled-in by a care giver rather than a parent.

Gender (female): Pupils were asked their gender; we recoded the variable to distinguish female pupils (coded as 1) from male pupils (coded as 0 ).

Immigration background: the country of birth of pupils and parents was obtained from Dutch administrative records. We distinguish between pupils with two native born parents (coded as 0 ) from pupils who were not born in the Netherlands (First generation, coded as 1) and pupils with at least one foreign born parent (Second generation, coded as 2).

\section{$5 \quad$ Analyses}

We analyze these data in two steps. First, we use sequence analyses to identify clusters of trajectories that archetypically characterize Dutch pupils' transition from school to work. Then, we use logistic regression to predict cluster membership, and assess the extent to which certain sequences are more likely for people with certain personality types and aspirations. We use Stata 16 for estimation (StataCorp 2019). To aid interpretation we present average marginal effects. To properly decompose direct and indirect effects of parental social class, we use the decomposition method described in Karlson \& Holm (2011) and make use of the khb ado in Stata (Kohler, Karlson, and Holm 2011). 
[Figure 1 about here]

\subsection{Sequence analyses}

Sequences consist of a finite set of categorical states: education, inactivity, and employment. Like a fingerprint, every person has an individual sequence pattern. However, because people are also part of the same institutional, social, and economic context, we can also expect great similarities between trajectories. Ordering and identifying these similarities and inferring generalities from them is the main task of sequence analysis. To do so, we rely on optimal matching which calculates a pairwise measure of dissimilarity given a pre-defined cost structure. We select the costs that are standard to optimal matching, where we set insertion/deletion costs as 2 and substitution costs as $1^{\mathrm{i}}$. This is equivalent to the Longest Common Subsequence (LCS) (Elzinga 2008; Studer and Ritschard 2016). We chose this because we are primarily concerned with the length of NEET spells for which the classical optimal matching is a reasonable choice (Studer and Ritschard 2016). These costs quantify how many changes would need to be made to one sequence in order for two sequences to be equal. We use the TraMinerR package for all steps related to the sequence analysis (Gabadinho et al. 2011). Then, we use hierarchical clustering after which we extract typologies of school-to-work trajectories. We use complete linkage in the clustering step. We do so after consideration of Ward's and average linkage (see appendix). While Ward's algorithm is the most commonly used clustering algorithm in sequence analysis applications, we opted for complete linkage because it gave us a clear NEET cluster and a clear School-to-Work cluster. Other linkage functions such as centroid or single linkage will split the data in one large group and one single observation which is the most different from the rest. This is not useful for our application. 
We align sequences on the first non-education state observed since January 2001. We then exclude the month of August in every year of observation to exclude seasonal regularities in the data that are most likely related to the summer break. During August, some pupils change schools and thus are not registered consecutively in education. The economic or educational activity in August is therefore not easy to interpret and would likely result in faulty interpretation of school leaving. We also exclude sequences that have missing states for more than $10 \%$ of the observation as mentioned in the data section.

For our main analyses we extract two clusters. This solution was selected after inspection of the following cluster solutions (see cluster tree in the appendix).

Note that we do not claim that this solution is the right cluster solution simply because there is none (Warren et al. 2015). Such is the nature of hierarchical clustering. In fact, there are as many cluster solutions possible as there are observations in the data. We also do not give an estimate of how many solutions there might be. Still, we do claim that our chosen solution is the most useful one. It is the most relevant and parsimonious typology to answer our research question.

Figure 1 displays the two main typologies, which can easily be described as successful and unsuccessful school-to-work transitions. The first trajectory mainly represents the classical school-to-work transition for youth who follow vocational training or higher education and then find employment. The second cluster ends with the majority of young people being NEET, twelve years after leaving secondary school. Though some trajectories start in education, especially vocational training, or work, around $80 \%$ are NEET in the end. In Table 3, we show average marginal effects from logistic regression models to explain these patterns. Similar patterns also emerge when we take another popular clustering algorithm, ward's or average linkage function. Or when we only keep young people with at least one month spent in NEET during the observation period.

[Figure 1 about here] 


\subsection{Logistic regression}

We use logistic regression to explore the extent to which the probability to follow an unsuccessful school-to-work transition characterized by frequent, long-term periods as NEET, compared to the alternative pathway can be explained by social class (Model 1), human capital (Model 2), aspirational alignment (Model 3), and resilience (Model 4). Note that in all models, shown in Table 3, we control for potential confounders: gender, immigration background, parental household structure, and age. As the dependent variable we take whether a young person follows the NEET trajectory or the alternative. We present average marginal effects. First, we report associations of the control variables. Young people who were not born in the Netherlands $(\mathrm{AME}=.019, \mathrm{p}<.01)$ have a higher probability of following a long-term NEET trajectory than young people with two Dutch parents. The associations of immigration background hold over all four models. Also, in all models, young women are more likely to become long-term NEET than young men $(\mathrm{AME}=.020, \mathrm{p}<.001)$. The household status variable is not significant in any model. Age is related to a higher probability to become NEET as well $(\mathrm{AME}=.008, \mathrm{p}<.001)$.

Model 1 shows that social class is negatively associated with following a long-term NEET trajectory. Having parents with lower education increases the probability of their children becoming long-term NEET compared to having parents with at least secondary education $(\mathrm{AME}=.023, \mathrm{p}<.001)$. University educated parents further reduce the likelihood to become NEET $($ AME $=-.016, p<.01)$ compared to parents with secondary education. Once we add the human capital measures in Model 2, parental education becomes insignificant, pointing at the theorized mediation via education. Short-term parental joblessness does not change the probability to follow a long-term NEET trajectory. However, long-term parental joblessness significantly increases the probability to follow a long-term NEET trajectory (AME $=.029, p$ $<.001)$. This association is stable over all four models. Living in rented housing compared to owned housing is also correlated with a higher probability to become long-term NEET (AME 
$=.044, \mathrm{p}<.001)$. A one percent increase in parental household income is correlated with a decrease in the probability to become long-term NEET by half a percent (AME $=-.005, p<$ .05). However, this association does not hold in later models. Based on Model 1 we can accept Hypothesis 1 which predicted that a higher social class background lowers the risk to become NEET.

[Table 3 about here]

Model 2 adds measures of human capital. Compared to those who followed the vocational track, those from the general tracks are significantly less likely to follow a NEET trajectory (AME $($ HAVO $)=-.053, \mathrm{p}<.001 ;$ AME $($ VWO $)=-.063, \mathrm{p}<.001)$. Practical education increases the probability to become long-term NEET compared to VMBO (AME $=.067, \mathrm{p}<.001$ ). Education, which is not further observed, hence the label "Other (assigned)", is also significantly related to a long-term NEET trajectory $(\mathrm{AME}=.097, \mathrm{p}<.001)$. Note also that age is now stronger correlated with becoming NEET. Before including education in the model, the correlation of age was likely suppressed because the general tracks take longer to finish and also offer better labor market prospects. Now that education is included, age more likely represents grade retention and thus is a proxy for human capital as well. All in all, this supports Hypothesis 2a. However, Model 2 also shows that in addition to the educational track, cognitive skills do not add to the explanation of becoming a long-term NEET, which refutes Hypothesis $2 b$.

Model 3 adds the measure of aspirational alignment. The reference category is young people who aspired to a professional occupation and followed the general education track. Compared to them, there are no significant differences in the probabilities to become NEET for pupils with misaligned or uncertain aspirations. This goes against the prediction made in Hypothesis 3a that uncertainty would put a pupil at a higher risk to become long-term NEET. There is also 
no evidence to accept Hypothesis 3b, because misaligned occupational aspirations do not increase the likelihood to become NEET.

In Model 4 we add the measure of resilient personality. The likelihood of following a NEET trajectory does indeed change to the favor of young people with a resilient personality (AME = $-0.036, \mathrm{p}<.01)$. Thus, we can accept Hypothesis 4, because young people with resilient personalities are less likely to become NEET than those with a non-resilient personality.

In addition to independent effects, we hypothesized that social class would be mediated through education, resilience, and aspirational alignment. In Table 4 we show results from the KHB decomposition analysis. The columns show the mediators (z-variables) education, resilience, and aspirational alignment. For education, we see that $24.98 \%$ of the total association of lower social class background are due to the educational track pupils are sorted in. For resilient personality and aspirational alignment, mediation is negligible with $1.15 \%$ and $1.68 \%$. Thus, we can accept Hypothesis 5a but not Hypotheses 5b and 5c.

\section{[Table 4 about here]}

We also modelled the moderation of social class by pupil's education, personality, and aspirations. To aid interpretation, we computed a binary indicator of low socioeconomic status which we will interact with the variables of interest. We define lower socioeconomic status parents as earning below median household income, living in rental housing, having been jobless at least once and not having a university education. In Figure 2, we show three panels of figures, each showing one set of interactions. We start with Panel A, which shows the predicted probabilities for youth to become NEET on the y-axis depending on their education (x-axis) and their parental social class (dot markers). We see that for youth who followed HAVO or VWO a low social class background (Low SES = Yes) does not make a significant difference to the probabilities to become long-term NEET as compared to not having a low 
socioeconomic background. However, for $\mathrm{VMBO}$, or other education, the negative effect of low social class is increased. In other words, for low educated youth, coming from a high social class serves as a protector. We conclude that Hypothesis $6 \mathrm{a}$ is accepted: social class moderates the effect of education.

In Panel $B$ we see that a lower social class increases the probability to become NEET significantly for non-resilient youth compared to non-resilient youth without a low social class background. We also see that for resilient youth, there is no significant differences to become NEET. This means that social class moderates the effect of resilience and we therefore accept Hypothesis $6 b$.

Panel C shows that the effect of lower social class for the most part does not significantly vary over the different levels of aspirational alignment. However, for the uncertain categories (vocational uncertain, uncertain professional, uncertain non-professional, orientation less), the risk of becoming NEET is slightly elevated for those with a lower social class background, although the difference is on the borderline of significance. We conclude that we can only partly accept Hypothesis 6c.

\section{Conclusion}

We set-out to answer why some young people in the Netherlands become NEET and others successfully transition from school to work. More specifically, we asked to what extent and how human capital, social class, occupational aspirations, and personality predict a school-towork trajectory that is predominantly characterized by time spent in NEET. First, our findings have implications for ongoing research and debates about NEET young people - who they are and how to prevent youth from becoming NEET. Our sequence analysis shows that many NEET trajectories begin at an early age, often after early-school leaving. Many of these are characterized by long-term disengagement and path-dependency. We also show that parental education is partially mediated through young people's education, but that there are considerable direct effects of parental education as well as other social background measures, 
such as parental joblessness and immigration background. Hence, we subscribe to an interpretation of long-term NEETs being young people subjected to multiple risk factors. One important factor seems to be early school leaving. Certainly, in an occupationally structured labor market such as the Netherlands, young people without any type of credentials will face more set-backs during the school to work transition (de Lange, Gesthuizen, and Wolbers 2014). Unlike previous research we do not find strong evidence that youth who had uncertain or misaligned occupational aspirations are more likely to follow long-term NEET trajectories, although uncertain aspirations seem to matter more for low SES youth. The fact that we find no strong results could be explained by the highly stratified educational system of the Netherlands in which pupils do not need to have clear plans because for the most part, they are streaming through whatever trajectory they were assigned to. Most research on uncertain and misaligned aspirations was focused on education systems without extensive tracking such as the US (Staff et al. 2010) or the UK (Yates et al. 2011). It might also be because our data measured aspirations at age 12, which may be too early. The two beforementioned studies have data from age 16 .

We also investigated the role of personality. We found that a resilient personality protects youth against becoming long-term NEET. Moreover, we find that being resilient decreases the NEET risk more strongly for low SES youth than for high SES youth. Notbeing resilient has a stronger negative impact for youth from lower class background than for youth from higher social class backgrounds. Resilience is thus a key asset, especially for lower social class youth. In addition, the protecting effect of resilience we find is about the same size as the effect for growing up in rented housing or having long-term jobless parents. Hence, if youth, especially low social class youth, lack this resilient personality traits, the predicted probability to become NEET might become a very real possibility for them.

Also, future research should further disentangle NEET youth. Sequence analysis has proven to be a useful tool to make sense of the manifold of school to work trajectories. Yet it might be 
worthwhile to also focus more on vulnerable sub-groups such as young women or children of immigrants. Finally, cross-national comparisons are needed to provide us with evidence of the role of institutions.

\section{$7 \quad$ References}

Aisenbrey, Silke, and Anette E. Fasang. 2010. 'New Life for Old Ideas: The 'Second Wave' of Sequence Analysis Bringing the 'Course' Back Into the Life Course." Sociological Methods \& Research 38(3):420-62.

Akse, Joyce, William W. Hale, Rutger CME Engels, Quinten AW Raaijmakers, and Wim HJ Meeus. 2004. "Personality, Perceived Parental Rejection and Problem Behavior in Adolescence." Social Psychiatry and Psychiatric Epidemiology 39(12):980-88.

Asendorpf, Jens B., Peter Borkenau, Fritz Ostendorf, and Marcel A. G. Van Aken. 2001. "Carving Personality Description at Its Joints: Confirmation of Three Replicable Personality Prototypes for Both Children and Adults." European Journal of Personality 15(3):169-98.

Bäckman, Olof, and Anders Nilsson. 2016. 'Long-Term Consequences of Being Not in Employment, Education or Training as a Young Adult. Stability and Change in Three Swedish Birth Cohorts." European Societies 18(2):136-57.

Bakker, Bart F. M., Johan van Rooijen, and Leo van Toor. 2014. "The System of Social Statistical Datasets of Statistics Netherlands: An Integral Approach to the Production of Register-Based Social Statistics." Statistical Journal of the IAOS 30(4):411-424.

Becker, Gary S. 1964. Human Capital: A Theoretical and Empirical Analysis, with Special Reference to Education. Chicago: The University of Chicago Press.

Bell, David N. F., and David G. Blanchflower. 2011. Youth Unemployment in Europe and the United States. Institute for the Study of Labor (IZA).

Block, Jeanne H., and John Block. 1980. "The Role of Ego-Control and Ego-Resiliency in the Organization of Behavior." Pp. 39-101 in Development of cognition, affect, and social relations: The Minnesota symposia on child psychology.

Borghans, Lex, Angela L. Duckworth, James J. Heckman, and Bart ter Weel. 2008. "The Economics and Psychology of Personality Traits." Journal of Human Resources 43(4):972-1059.

Boudon, Raymond. 1974. Education, Opportunity, and Social Inequality: Changing Prospects in Western Society. New York: Wiley.

Bourdieu, P., and J. Passeron. 1977. Reproduction in Education, Society and Culture. London: Sage.

Bowles, Samuel, Herbert Gintis, and Melissa Osborne. 2001. "Incentive-Enhancing Preferences: Personality, Behavior, and Earnings." American Economic Review 91(2):155-58. 
Brzinsky-Fay, Christian. 2014. "The Measurement of School-to-Work Transitions as Processes About Events and Sequences." European Societies 16(2):213-32.

Burns, Gary N., Megan B. Morris, Natalie Rousseau, and Josh Taylor. 2013. "Personality, Interests, and Career Indecision: A Multidimensional Perspective." Journal of Applied Social Psychology 43(10):2090-99.

Bynner, John, and Samantha Parsons. 2002. "Social Exclusion and the Transition from School to Work: The Case of Young People Not in Education, Employment, or Training (NEET)." Journal of Vocational Behavior 60(2):289-309.

Cammeraat, Emile, Egbert Jongen, and Pierre Koning. 2017. "Preventing NEETs During the Great Recession." CPB Discussion Paper (365).

Caspi, Avshalom, B. R. Entner Wright, Terrie E. Moffitt, and P. A. Silva. 1998. "Early Failure in the Labor Market: Childhood and Adolescent Predictors of Unemployment in the Transition to Adulthood." American Sociological Review 63(June):424-51.

Coleman, James S. 1988. "Social Capital in the Creation of Human-Capital." American Journal of Sociology 94:95-120.

Coles, Bob, Sandra Hutton, Jonathan Bradshaw, Gary Craig, Christine Godfrey, and Julia Johnson. 2002. Literature Review of the Costs of Being "Not in Education, Employment or Training” at Age 16-18. Social Policy Research Unit: University of York, University of Hull.

Croll, Paul. 2008. "Occupational Choice, Socio-economic Status and Educational Attainment: A Study of the Occupational Choices and Destinations of Young People in the British Household Panel Survey." Research Papers in Education 23(3):243-68.

Damian, R. I., R. Su, M. Shanahan, U. Trautwein, and B. W. Roberts. 2015. "Can Personality Traits and Intelligence Compensate for Background Disadvantage? Predicting Status Attainment in Adulthood." Journal of Personality and Social Psychology 109(3):47389.

Dennissen, J. J., J. B. Asendorpf, and M. A. van Aken. 2008. "Childhood Personality Predicts Long-Term Trajectories of Shyness and Aggressiveness in the Context of Demographic Transitions in Emerging Adulthood." Journal of Personality 76(1):67-99.

Du Bois-Reymond, Manuela. 1998. “'I Don't Want to Commit Myself Yet': Young People's Life Concepts." Journal of Youth Studies 1(1):63-79.

Elder, Glen H. Jr, Monica Kirkpatrick Johnson, and Robert Crosnoe. 2003. "The Emergence and Development of Life Course Theory." Pp. 3-19 in Handbook of the Life Course, edited by J. T. Mortimer and M. Shanahan. New York: Kluwer.

Elzinga, Cees H. 2008. Sequence Analysis: Metric Representations of Categorical Time Series. Amsterdam: Department of Social Science Research Methods,Vrije Universiteit.

Erikson, Robert, John H. Goldthorpe, Michelle Jackson, Meir Yaish, and David R. Cox. 2005. "On Class Differentials in Educational Attainment." Proceedings of the National Academy of Sciences of the United States of America 102(27):9730-33. 
Eurofound. 2012. NEETs - Young People Not in Employment, Education or Training: Characteristics, Costs and Policy Responses in Europe. Luxembourg: Publications Office of the European Union.

Eurofound. 2016. Exploring the Diversity of NEETs. Luxembourg: Publications Office of the European Union.

Farkas, George. 2003. "Cognitive Skills and Noncognitive Traits and Behaviors in Stratification Processes.” Annual Review of Sociology 29(1):541-62.

Ferguson, Sarah L., and Darrel M. Hull. 2018. "Personality Profiles: Using Latent Profile Analysis to Model Personality Typologies." Personality and Individual Differences 122:177-83.

Furlong, Andy. 2006. "Not a Very NEET Solution.” Work, Employment and Society 20(3):55369.

Furlong, Andy, and Andy Biggart. 1999. 'Framing 'Choices': A Longitudinal Study of Occupational Aspirations among 13- to 16-year-olds." Journal of Education and Work 12(1):21-35.

Gabadinho, Alexis, G. Ritschard, M. Studer, and Nicolas S. Müller. 2011. "Mining Sequence Data in R with the TraMineR Package: A User's Guide."

Gelissen, John, and Paul M. de Graaf. 2006. "Personality, Social Background, and Occupational Career Success.” Social Science Research 35(3):702-26.

Germeijs, Veerle, and Karine Verschueren. 2011. "Indecisiveness and Big Five Personality Factors: Relationship and Specificity." Personality and Individual Differences 50(7):1023-28.

Gottfredson, Linda S. 1981. "Circumscription and Compromise: A Developmental Theory of Occupational Aspirations.” Journal of Counseling Psychology 28(6):545-79.

Gregg, Paul, and Emma Tominey. 2005. "The Wage Scar from Male Youth Unemployment." Labour Economics 12(4):487-509.

Guay, Frédéric, Caroline Senecal, Lysanne Gauthier, and Claude Fernet. 2003. "Predicting Career Indecision: A Self-Determination Theory Perspective." Journal of Counseling Psychology 50(2):165-77.

Heckman, James J., Jora Stixrud, and Sergio Urzua. 2006. "The Effects of Cognitive and Noncognitive Abilities on Labor Market Outcomes and Social Behavior." Journal of Labor Economics 24(3):411-82.

Hendriks, A. A. Jolijn, William K. B. Hofstee, and Boele De Raad. 1999. "The Five-Factor Personality Inventory (FFPI).” Personality and Individual Differences 27(2):307-25.

Hirschi, Andreas. 2012. "Vocational Identity Trajectories: Differences in Personality and Development of Well-Being." European Journal of Personality 26(1):2-12.

Holtmann, Anne Christine, Laura Menze, and Heike Solga. 2017. "Persistent Disadvantages or New Opportunities? The Role of Agency and Structural Constraints for Low-Achieving 
Adolescents' School-to-Work Transitions." Journal of Youth and Adolescence 46(10):2091-2113.

Jencks, Christopher. 1979. Who Gets Ahead? The Determinants of Economic Success in America. New York: Basic Books.

Karlson, Kristian Bernt, and Anders Holm. 2011. "Decomposing Primary and Secondary Effects: A New Decomposition Method." Research in Social Stratification and Mobility 29(2):221-37.

Kerckhoff, Alan C. 2003. "From Student to Worker." in Handbook of the Life Course, edited by J. T. Mortimer and M. Shanahan. New York: Kluwer Academic/Plenum Publishers.

Kohler, U., K. B. Karlson, and A. Holm. 2011. "Comparing Coefficients of Nested Nonlinear Probability Models." Stata Journal 11(3):420-38.

Kuyper, Hans, Miranda J. Lubbers, and Margarethe P. C. Van der Werf. 2003. VOCL'99-1: Technisch Rapport. Groningen: GION.

de Lange, Marloes, Maurice Gesthuizen, and Maarten H. J. Wolbers. 2014. "Youth Labour Market Integration Across Europe.” European Societies 16(2):194-212.

Lanza, S. T., B. L. Rhoades, R. L. Nix, M. T. Greenberg, and Group Conduct Problems Prevention Research. 2010. "Modeling the Interplay of Multilevel Risk Factors for Future Academic and Behavior Problems: A Person-Centered Approach.” Development and Psychopathology 22(2):313-35.

Lareau, Annette. 2000. Home Advantage: Social Class and Parental Intervention in Elementary Education. Lanham: Rowman \& Littlefield.

Lin, Nan. 2001. Social Capital: A Theory of Social Structure and Action. Cambridge: Cambridge University Press.

Logan, John Allen. 1996. "Opportunity and Choice in Socially Structured Labor Markets." American Journal of Sociology 102(1):114-60.

Luijkx, Ruud, and Maarten H. J. Wolbers. 2009. "The Effects of Non-Employment in Early Work-Life on Subsequent Employment Chances of Individuals in The Netherlands." European Sociological Review 25(6):647-60.

Maguire, S. 2015. "NEET, Unemployed, Inactive or Unknown - Why Does It Matter?" Educational Research 57(2):121-32.

Martincin, Kelly M., and Graham B. Stead. 2014. "Five-Factor Model and Difficulties in Career Decision Making." Journal of Career Assessment 23(1):3-19.

McCrae, Robert R., and Paul T. Costa. 1987. "Validation of the Five-Factor Model of Personality across Instruments and Observers." Journal of Personality and Social Psychology 52:81-90.

McVicar, Duncan, and Michael Anyadike-Danes. 2002. "Predicting Successful and Unsuccessful Transitions from School to Work by Using Sequence Methods." Journal of the Royal Statistical Society Series A: Statistics in Society 165:317-34. 
Merz, Erin L., and Scott C. Roesch. 2011. "A Latent Profile Analysis of the Five Factor Model of Personality: Modeling Trait Interactions." Personality and Individual Differences 51(8):915-19.

Mirowsky, John, and Catherine E. Ross. 2003. Education, Social Status, and Health. New York: Aldine De Gruyter.

Ng-Knight, Terry, and Ingrid Schoon. 2017. "Can Locus of Control Compensate for Socioeconomic Adversity in the Transition from School to Work?" Journal of Youth and Adolescence 46(10):2114-2128.

Nieuwenhuis, Jaap, Rongqin Yu, Susan Branje, Wim Meeus, and Pieter Hooimeijer. 2016. "Neighbourhood Poverty, Work Commitment and Unemployment in Early Adulthood: A Longitudinal Study into the Moderating Effect of Personality." PLoS One 11(12):e0167830.

Oreopoulos, Philip. 2007. "Do Dropouts Drop out Too Soon? Wealth, Health and Happiness from Compulsory Schooling." Journal of Public Economics 91(11-12):2213-29.

Pfeffer, F. T. 2008. "Persistent Inequality in Educational Attainment and Its Institutional Context." European Sociological Review 24(5):543-65.

Pinquart, Martin, Linda P. Juang, and Rainer K. Silbereisen. 2003. "Self-Efficacy and Successful School-to-Work Transition: A Longitudinal Study." Journal of Vocational Behavior 63(3):329-46.

Roberts, Brent W., Nathan R. Kuncel, Rebecca Shiner, Avshalom Caspi, and Lewis R. Goldberg. 2007. "The Power of Personality: The Comparative Validity of Personality Traits, Socioeconomic Status, and Cognitive Ability for Predicting Important Life Outcomes." Perspectives on Psychological Science 2(4):313-45.

Robins, Richard W., Oliver P. John, Avshalom Caspi, Terrie E. Moffitt, and Magda Stouthamer-Loeber. 1996. "Resilient, Overcontrolled, and Undercontrolled Boys: Three Replicable Personality Types." Journal of Personality and Social Psychology 70(1):157-71.

Sabates, Ricardo, Angel L. Harris, and Jeremy Staff. 2011. "Ambition Gone Awry: The LongTerm Socioeconomic Consequences of Misaligned and Uncertain Ambitions in Adolescence." Social Science Quarterly 92(4):959-77.

Schmillen, Achim, and Matthias Umkehrer. 2013. The Scars of Youth: Effects of Early-Career Unemployment on Future Unemployment Experience. IAB-Discussion Paper.

Schoon, Ingrid, and Samantha Parsons. 2002. "Teenage Aspirations for Future Careers and Occupational Outcomes." Journal of Vocational Behavior 60(2):262-88.

Sewell, William H., Archibald O. Haller, and Alejandro Portes. 1969. "The Educational and Early Occupational Attainment Process." American Sociological Review 34(1):82-92.

Shanahan, Michael J. 2000. "Pathways to Adulthood in Changing Societies: Variability and Mechanisms in Life Course Perspective." Annual Review of Sociology 26:667-92. 
Shanahan, Michael J., Shawn Bauldry, Brent W. Roberts, Ross Macmillan, and Russo Russo. 2014. "Personality and the Reproduction of Social Class." Social Forces 93(1):209-40.

Shavit, Yossi, and Walter Müller. 1998. From School to Work. A Comparative Study of Educational Qualifications and Occupational Destinations. Oxford: Clarendon Press.

Spence, Michael. 1973. “Job Market Signaling.” Quarterly Journal of Economics 87(3):35574.

Staff, Jeremy, Angel Harris, Ricardp Sabates, and Laine Briddell. 2010. "Uncertainty in Early Occupational Aspirations: Role Exploration or Aimlessness?" Social Forces 89(2):659_ 84.

Staff, Jeremy, and Jeylan T. Mortimer. 2008. "Social Class Background and the School-toWork Transition." New Directions for Child and Adolescent Development (119):55-69.

StataCorp. 2019. Stata Statistical Software: Release 16. College Station, TX: StataCorp LLC.

Steijn, Bram, Ariana Need, and Maurice Gesthuizen. 2006. "Well Begun, Half Done?: LongTerm Effects of Labour Market Entry in the Netherlands, 1950-2000." Work, Employment and Society 20(3):453-72.

Studer, M., and G. Ritschard. 2016. "What Matters in Differences between Life Trajectories: A Comparative Review of Sequence Dissimilarity Measures." Journal of the Royal Statistical Society Series A-Statistics in Society 179(2):481-511.

Thompson, Ron. 2011. "Individualisation and Social Exclusion: The Case of Young People Not in Education, Employment or Training." Oxford Review of Education 37(6):785802 .

Tokar, David M., Ann R. Fischer, and Linda Mezydlo Subich. 1998. "Personality and Vocational Behavior: A Selective Review of the Literature, 1993-1997." Journal of Vocational Behavior 53(2):115-53.

van Tubergen, Frank, and Beate Volker. 2014. "Inequality in Access to Social Capital in the Netherlands." Sociology-the Journal of the British Sociological Association 49(3):52138.

Uysal, Selver Derya, and Winfried Pohlmeier. 2011. "Unemployment Duration and Personality." Journal of Economic Psychology 32(6):980-92.

Van Berkel, K. 1999. 'Steekproef Voor Schoolloopbaan Onderzoek VOCL’99.”

van der Velden, Rolf K. W., and Maarten H. J. Wolbers. 2006. "How Much Does Education Matter and Why?: The Effects of Education on Socio-Economic Outcomes among School-Leavers in the Netherlands." European Sociological Review 23(1):65-80.

Verhaeghe, Peter-Paul, Yaojun Li, and Bart Van de Putte. 2013. "Socio-Economic and Ethnic Inequalities in Social Capital from the Family among Labour Market Entrants." European Sociological Review 29(4):683-94. 
Vuolo, Mike, Jeremy Staff, and Jeylan T. Mortimer. 2012. "Weathering the Great Recession: Psychological and Behavioral Trajectories in the Transition from School to Work." Developmental Psychology 48(6):1759-73.

Warren, John Robert, Liying Luo, Andrew Halpern-Manners, James M. Raymo, and Alberto Palloni. 2015. "Do Different Methods for Modeling Age-Graded Trajectories Yield Consistent and Valid Results?" American Journal of Sociology 120(6):1809-56.

Yates, Scott, Angel Harris, Ricardo Sabates, and Jeremy Staff. 2011. "Early Occupational Aspirations and Fractured Transitions: A Study of Entry into 'NEET' Status in the UK." Journal of Social Policy 40(03):513-34.

Yates, Scott, and M. Payne. 2007. 'Not so NEET? A Critique of the Use of 'NEET' in Setting Targets for Interventions with Young People." Journal of Youth Studies 9(3):329-44. 
Table 1: Alignment typology adapted and extended from Sabates et al (2011)

\begin{tabular}{|c|c|c|c|c|}
\hline \multirow{5}{*}{$\begin{array}{l}\text { Educational } \\
\text { expectations }\end{array}$} & \multicolumn{3}{|c|}{ Occupational aspirations } & \multirow[b]{2}{*}{ Don't know/missing } \\
\hline & & Professional & Nonprofessional & \\
\hline & Academic & $\begin{array}{c}\text { I. Aligned (High) } \\
12 \%\end{array}$ & $\begin{array}{c}\text { II. Misaligned (Over) } \\
8 \%\end{array}$ & $\begin{array}{l}\text { III. Academic } \\
\text { uncertain } \\
20 \%\end{array}$ \\
\hline & Vocational & $\begin{array}{c}\text { IV. Misaligned (Under) } \\
1 \%\end{array}$ & $\begin{array}{l}\text { V. Aligned (low) } \\
5 \%\end{array}$ & $\begin{array}{c}\text { VI. Vocational } \\
\text { uncertain } \\
6 \%\end{array}$ \\
\hline & $\begin{array}{c}\text { Don't } \\
\text { know/missing }\end{array}$ & $\begin{array}{c}\text { VII. Uncertain } \\
\text { professional } \\
7 \%\end{array}$ & $\begin{array}{c}\text { VIII. Uncertain } \\
\text { nonprofessional } \\
12 \%\end{array}$ & $\begin{array}{c}\text { IX. Orientation less } \\
28 \%\end{array}$ \\
\hline
\end{tabular}


Table 2: Descriptive statistics

\begin{tabular}{|c|c|c|c|}
\hline Variable & Mean/Percentage & Std. Dev. & $\mathrm{N}$ \\
\hline \multicolumn{4}{|l|}{ Gender } \\
\hline Male & $49.16 \%$ & & 5,570 \\
\hline Female & $50.84 \%$ & & 5,385 \\
\hline \multicolumn{4}{|l|}{ Immigration background } \\
\hline Dutch & $86.36 \%$ & & 9,461 \\
\hline First generation & $2.67 \%$ & & 292 \\
\hline Second generation & $10.97 \%$ & & 1,202 \\
\hline Age at leaving school & 17.39 & 1.08 & 10,955 \\
\hline \multicolumn{4}{|l|}{ Track before leaving school } \\
\hline Practical & $6.54 \%$ & & 717 \\
\hline VMBO & $37.10 \%$ & & 4,064 \\
\hline HAVO & $26.91 \%$ & & 2,948 \\
\hline VWO & $20.16 \%$ & & 2,209 \\
\hline Other (assigned) & $9.28 \%$ & & 1,017 \\
\hline Total score entry test & 37.79 & 10.48 & 10,955 \\
\hline \multicolumn{4}{|l|}{ Occupational alignment } \\
\hline I. Aligned (High) & $11.88 \%$ & & 1,301 \\
\hline II. Misaligned (Over) & $8.47 \%$ & & 928 \\
\hline III. Academic uncertain & $20.00 \%$ & & 2,191 \\
\hline IV. Misaligned (Under) & $1.28 \%$ & & 140 \\
\hline V. Aligned (Low) & $5.29 \%$ & & 580 \\
\hline VI. Vocational uncertain & $5.58 \%$ & & 611 \\
\hline VII. Uncertain professional & $7.00 \%$ & & 767 \\
\hline VIII. Uncertain nonprofessional & $12.40 \%$ & & 1,358 \\
\hline IX. Orientaton less & $28.11 \%$ & & 3,079 \\
\hline \multicolumn{4}{|l|}{ Personality traits } \\
\hline Emotional stability & 1.07 & 0.91 & 10,955 \\
\hline Extraversion & 1.19 & 0.86 & 10,955 \\
\hline Conscientiousness & 0.38 & 1.03 & 10,955 \\
\hline Agreeableness & 1.75 & 1.10 & 10,955 \\
\hline Autonomy & 0.48 & 0.86 & 10,955 \\
\hline \multicolumn{4}{|l|}{ Personality type } \\
\hline Resilient & $94.82 \%$ & & 10,387 \\
\hline Non-resilient & $5.18 \%$ & & 568 \\
\hline \multicolumn{4}{|l|}{ Household status } \\
\hline Two parents & $92.53 \%$ & & 10,137 \\
\hline Single parent & $6.85 \%$ & & 750 \\
\hline Care taker & $0.62 \%$ & & 68 \\
\hline \multicolumn{4}{|l|}{ Parental education } \\
\hline Primary & $23.54 \%$ & & 2,579 \\
\hline Secondary & $44.33 \%$ & & 4,856 \\
\hline Tertiary & $32.13 \%$ & & 3,520 \\
\hline \multicolumn{4}{|l|}{ Parental joblessness history } \\
\hline Never & $51.77 \%$ & & 5,671 \\
\hline
\end{tabular}




\begin{tabular}{|c|c|c|c|}
\hline Variable & Mean/Percentage & Std. Dev. & $\mathrm{N}$ \\
\hline 1 to 2 years & $26.33 \%$ & & 2,884 \\
\hline more than 2 years & $21.91 \%$ & & 2,400 \\
\hline Household income in $1000 €$ & 42.54 & 22.95 & 10,955 \\
\hline \multicolumn{4}{|l|}{ Homeown } \\
\hline Owned & $73.53 \%$ & & 8,055 \\
\hline Rented & $26.47 \%$ & & 2,900 \\
\hline \multicolumn{4}{|l|}{ Educational expectation (Pupil) } \\
\hline Academic & $40.35 \%$ & & 4,420 \\
\hline Vocational & $12.15 \%$ & & 1,331 \\
\hline Don't know/missing & $47.50 \%$ & & 5,204 \\
\hline Months NEET 13 years after leaving school & 11.54 & 24.11 & 10,955 \\
\hline Total N & & & 10,955 \\
\hline
\end{tabular}


Table 3: Logistic regression models, average marginal effects and standard errors shown.

\begin{tabular}{|c|c|c|c|c|}
\hline & Model 1 & Model 2 & Model 3 & Model 4 \\
\hline \multicolumn{5}{|c|}{ Social Class } \\
\hline \multicolumn{5}{|c|}{ Parental education, ref. cat.: Secondary } \\
\hline \multirow[t]{2}{*}{ Lower } & $0.023^{* * *}$ & 0.007 & 0.007 & 0.008 \\
\hline & 0.006 & 0.005 & 0.005 & 0.005 \\
\hline \multirow[t]{2}{*}{ Tertiary } & $-0.016^{* *}$ & -0.003 & -0.004 & -0.004 \\
\hline & 0.005 & 0.006 & 0.006 & 0.006 \\
\hline \multicolumn{5}{|c|}{ Parental unemployment history, ref. cat.: Never } \\
\hline \multirow[t]{2}{*}{1 to 2 years } & 0.008 & 0.006 & 0.006 & 0.005 \\
\hline & 0.005 & 0.005 & 0.005 & 0.005 \\
\hline \multirow[t]{2}{*}{ more than 2 years } & $0.029^{* * *}$ & $0.024^{* * *}$ & $0.024^{* * *}$ & $0.023^{* * *}$ \\
\hline & 0.006 & 0.006 & 0.006 & 0.006 \\
\hline \multicolumn{5}{|c|}{ Household ownership, ref. cat.: Owned } \\
\hline \multirow[t]{2}{*}{ Rented } & $0.044^{* * *}$ & $0.029^{* * *}$ & $0.028^{* * *}$ & $0.028^{* * *}$ \\
\hline & 0.006 & 0.006 & 0.006 & 0.006 \\
\hline \multirow[t]{2}{*}{ Parental household income, log } & $-0.005^{*}$ & -0.003 & -0.003 & -0.003 \\
\hline & 0.002 & 0.002 & 0.002 & 0.002 \\
\hline \multicolumn{5}{|c|}{ Skills } \\
\hline \multicolumn{5}{|c|}{ Education (last enrolled), ref. cat.: VMBO } \\
\hline \multirow[t]{2}{*}{ Practical } & - & $0.067^{* * *}$ & $0.067^{* * *}$ & $0.066^{* * *}$ \\
\hline & & 0.013 & 0.013 & 0.013 \\
\hline \multirow[t]{2}{*}{ HAVO } & - & $-0.053^{* * *}$ & $-0.054^{* * *}$ & $-0.053^{* * *}$ \\
\hline & & 0.008 & 0.008 & 0.008 \\
\hline \multirow[t]{2}{*}{ VWO } & - & $-0.063^{* * *}$ & $-0.064^{* * *}$ & $-0.063^{* * *}$ \\
\hline & & 0.009 & 0.009 & 0.009 \\
\hline \multirow[t]{2}{*}{ Other (assigned) } & - & $0.097^{* * *}$ & $0.098^{* * *}$ & $0.098^{* * *}$ \\
\hline & & 0.014 & 0.014 & 0.014 \\
\hline \multirow[t]{2}{*}{ Cognitive Abilities (SD) } & - & -0.000 & -0.001 & -0.001 \\
\hline & & 0.003 & 0.003 & 0.003 \\
\hline \multicolumn{5}{|c|}{ Aspirations } \\
\hline \multicolumn{5}{|c|}{ Occupational aspiration, ref. cat.: I. Aligned (High) } \\
\hline \multirow[t]{2}{*}{ II. Misaligned (Over) } & - & - & -0.007 & -0.008 \\
\hline & & & 0.011 & 0.011 \\
\hline \multirow[t]{2}{*}{ III. Academic uncertain } & - & - & -0.007 & -0.008 \\
\hline & & & 0.009 & 0.009 \\
\hline \multirow[t]{2}{*}{ IV. Misaligned (Under) } & - & - & -0.015 & -0.016 \\
\hline & & & 0.018 & 0.018 \\
\hline \multirow[t]{2}{*}{ V. Aligned (Low) } & - & - & -0.003 & -0.004 \\
\hline & & & 0.011 & 0.012 \\
\hline VI. Vocational uncertain & - & - & -0.012 & -0.014 \\
\hline & & & 0.011 & 0.011 \\
\hline VII. Uncertain & - & - & 0.004 & 0.004 \\
\hline & & & 0.012 & 0.012 \\
\hline VIII. Uncertain & - & - & -0.014 & -0.015 \\
\hline & & & 0.009 & 0.009 \\
\hline IX. Orientation less & - & - & -0.014 & -0.015 \\
\hline & & & 0.008 & 0.008 \\
\hline
\end{tabular}


Personality

Resilience type, ref. cat.: Non-Resilient

Resilient

$-0.036^{* * *}$

0.007

Controls

Gender, ref. cat.: Male

Female

$0.020^{\text {*** }}$
0.004
$0.008^{\text {*** }}$
0.002

$0.027^{* * * *}$

$0.027^{* * *}$

$0.027^{* * *}$

Age

0.002

0.004

0.004

0.004

$0.030^{* * *}$

$0.029^{* * * *}$

$0.030^{* * * *}$

Household status, ref. cat.: Two parents

Single parent

0.012

0.003

0.003

0.003

Caretaker

0.008

0.007

0.007

0.006

Caretaker

0.047

0.007

0.007

0.007

0.030

0.020

0.021

0.020

0.023

0.023

0.023

Immigration background, ref. cat.: Dutch

First generation

0.020

0.012

0.013

0.011

0.012

0.011

0.011

0.011

Second generation

$0.019^{* * *}$

$0.021^{*}$

$0.020^{* *}$

$0.020^{* *}$

0.007

Observations

10,955

0.007

0.007

0.007

Pseudo $R^{2}$

0.074

0.138

0.139

0.143 
Table 4: Decomposition of total, direct, and indirect associations (log odds) of parental education and NEET risk.

\begin{tabular}{llll}
\hline Indirect (Z-variable): & Education & Resilient personality & Aspirational alignment \\
\hline $\begin{array}{l}\text { Social class background } \\
\text { Lower }=1 \text { variable of interest) }\end{array}$ & & \\
Total (Reduced) & $1.320^{* * *}$ & $1.306^{* * *}$ & $1.299^{* * *}$ \\
Direct (Full) & $0.990^{* * *}$ & $1.291^{* * *}$ & $1.277^{* * *}$ \\
Indirect (Diff) & $0.330^{* * *}$ & 0.015 & $0.0219^{*}$ \\
\hline Percent due to Indirect: & $24.98 \%$ & $1.15 \%$ & $1.68 \%$ \\
\hline
\end{tabular}

Figure 1: Chronograms of two main trajectory types.
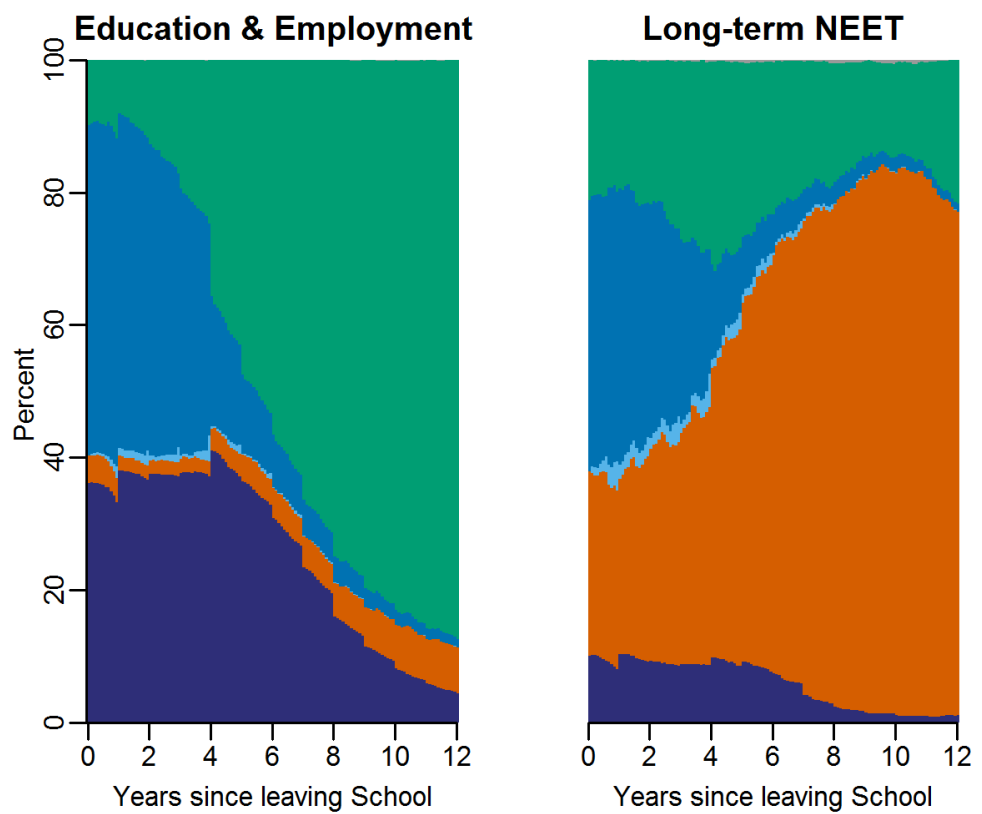

- Higher Education

NEET

- Secondary Education

- Vocational Training

Working

missing 
Figure 2: Marginal effects of education, personality and aspirational alignment at low levels of parental socio-economic status.

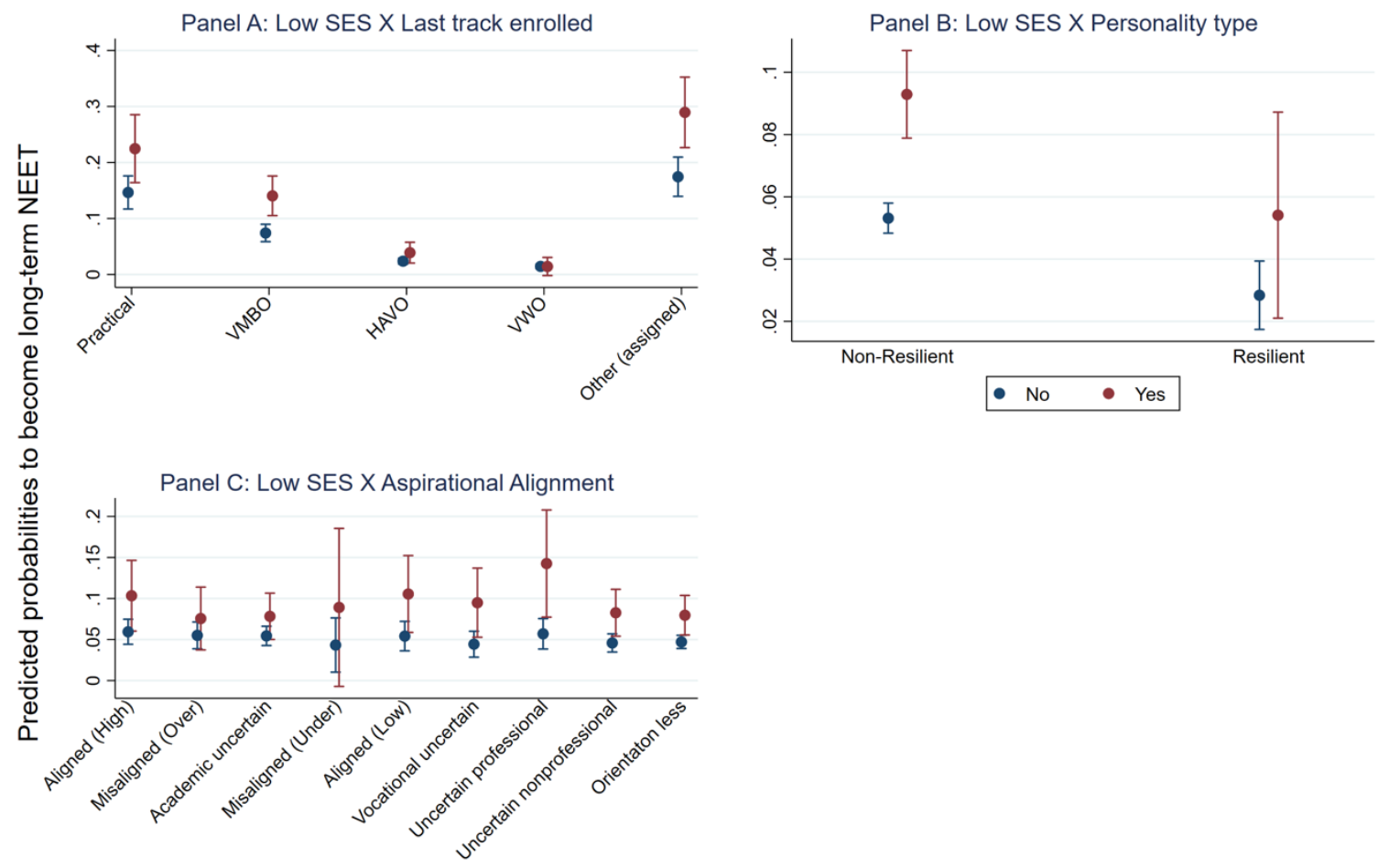




\section{Appendix A}

The following figure shows the data handling steps to prepare the sequence analysis. First, the whole sample and their activity between January 2001 to December 2018 is shown. Clearly visible is a regular "teeth" pattern in activity, which disappears after we exclude every observation from August. We do so to not mistaken regularities in the administration for real school-leaving. We then exclude episodes with more than $10 \%$ missing episodes and align on the first episode after school leaving. After that step, the horizontal axis changes from calendar time (2001 to 2018) to process time (years after school leaving)
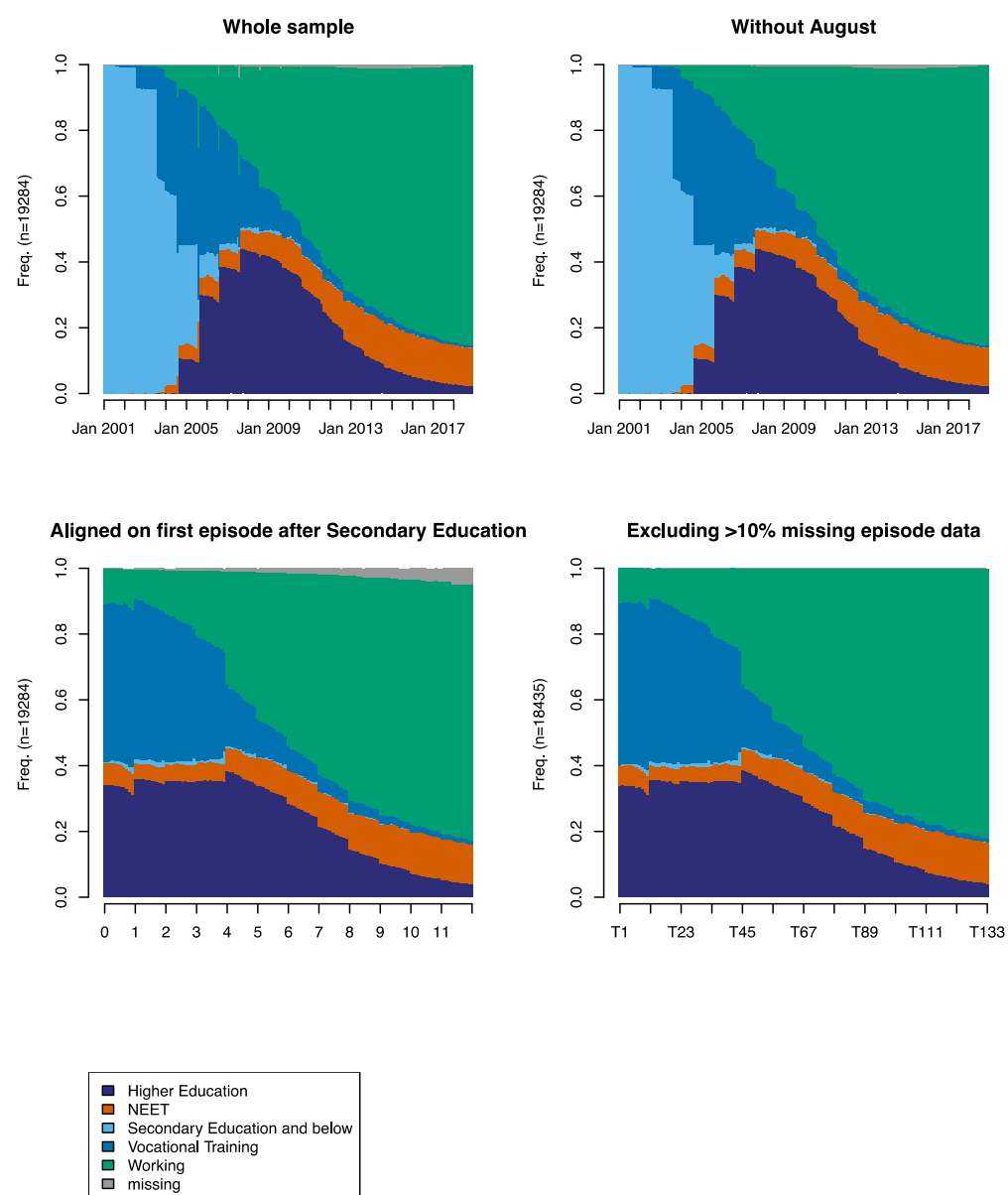
Appendix B: Overview of different cluster solutions by cost setting structures and cluster linkage functions.

\begin{tabular}{|c|c|c|c|c|c|c|}
\hline $\begin{array}{l}\text { Cost setting } \\
\text { structure }\end{array}$ & $\begin{array}{l}\text { Cluster linkage } \\
\text { function }\end{array}$ & $\begin{array}{l}\text { Long-term } \\
\text { NEET cluster } \\
\text { (Cluster } \\
\text { solution) }\end{array}$ & Label & $\begin{array}{l}\text { Months } \\
\text { NEET } \\
\text { (mean) }\end{array}$ & $\mathrm{N}$ & $\%$ \\
\hline \multirow[t]{7}{*}{$\mathrm{OM}(1,2) / \mathrm{LCS}$} & Ward's & Yes (3) & Employment & 9.66 & 7,770 & 42.15 \\
\hline & & & Further Education & 6.52 & 9,231 & 50.07 \\
\hline & & & Long-term NEET & 96.57 & 1,434 & 7.78 \\
\hline & Complete & Yes (2) & Employment/Education & 7.7 & 16,943 & 91.91 \\
\hline & & & Long-term NEET & 95.98 & 1,492 & 8.09 \\
\hline & Average & Yes (2) & Employment/Education & 8.90 & 17,309 & 93.89 \\
\hline & & & Long-term NEET & 106.32 & 1,126 & 6.11 \\
\hline \multirow[t]{3}{*}{ OMspell } & Ward's & No & - & - & - & \\
\hline & Complete & $\begin{array}{l}\text { No long-term } \\
\text { NEET pattern }\end{array}$ & - & - & - & \\
\hline & Average & $\begin{array}{l}\text { No, } \\
\text { singularities }\end{array}$ & - & - & - & \\
\hline \multirow[t]{3}{*}{ SVRspell } & Ward's & $\begin{array}{l}\text { No, } \\
\text { singularities }\end{array}$ & - & - & - & \\
\hline & Complete & $\begin{array}{l}\text { No, } \\
\text { singularities }\end{array}$ & - & - & - & \\
\hline & Average & $\begin{array}{l}\text { No, } \\
\text { singularities }\end{array}$ & - & - & - & \\
\hline
\end{tabular}


Appendix C: Cluster tree, complete linkage function, $O M(1,2) / L C S$

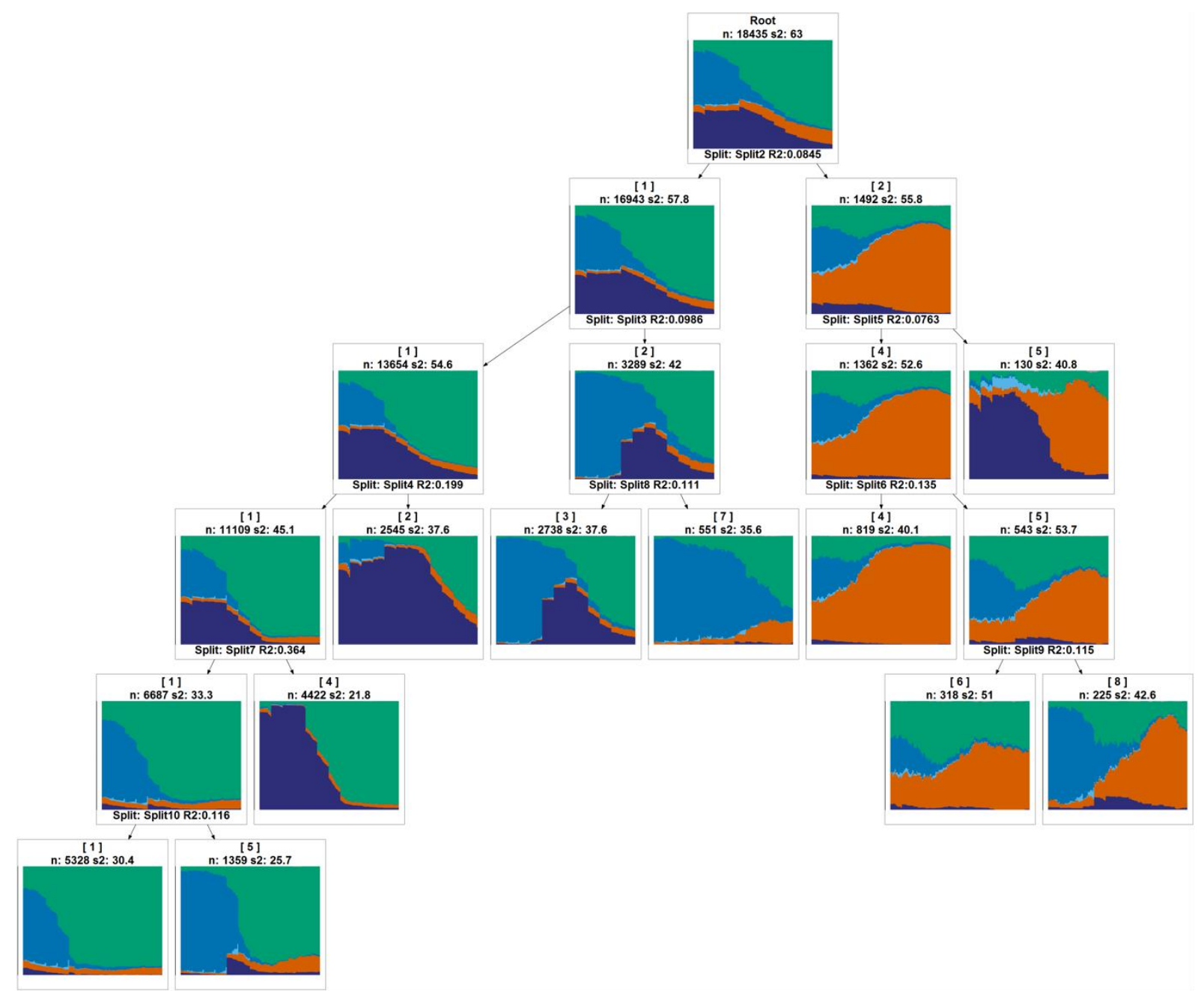


Appendix D: Cluster tree, Ward's linkage function, $O M(1,2) / L C S$

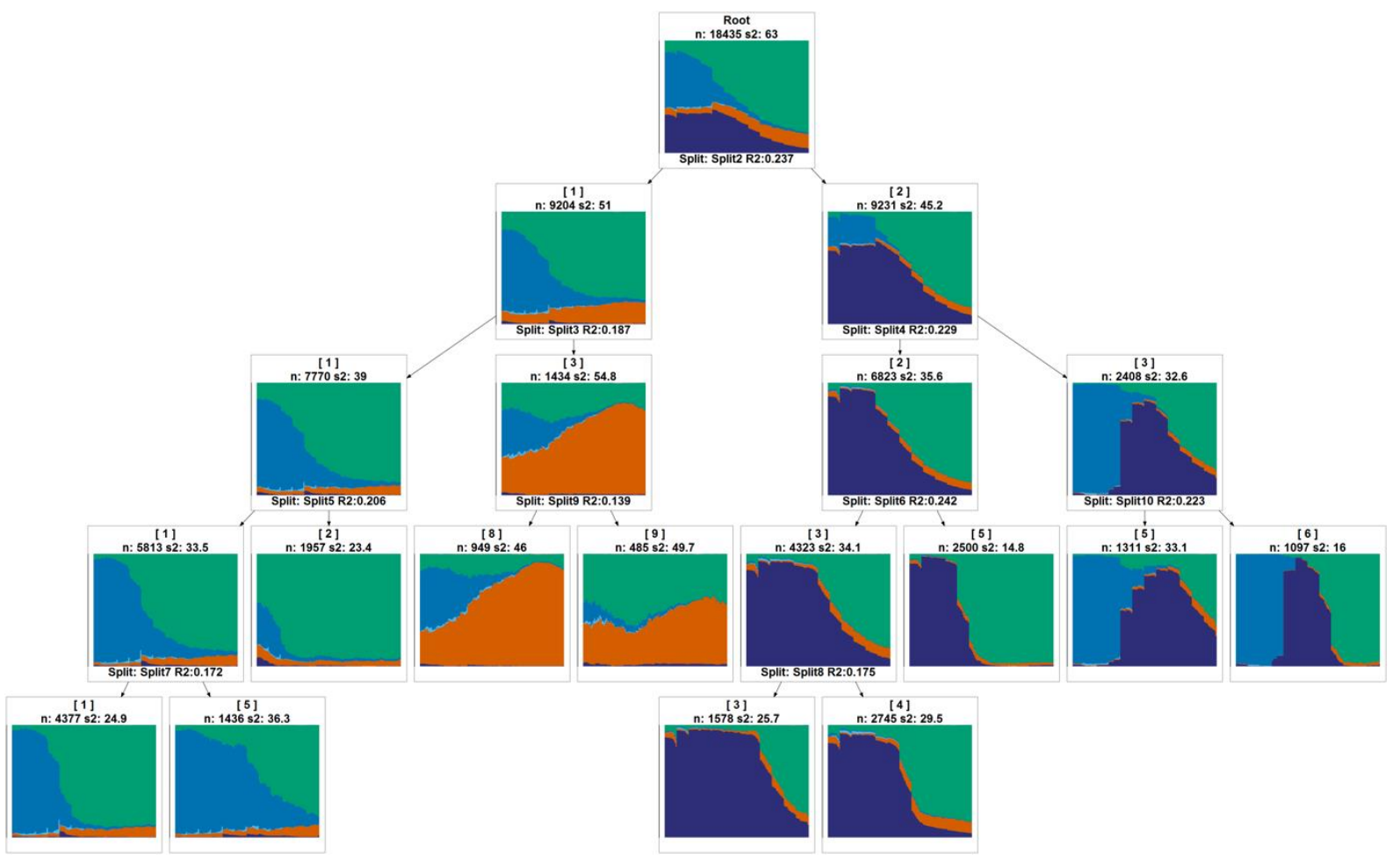


Appendix E: Cluster tree, Average linkage function, $O M(1,2) / L C S$

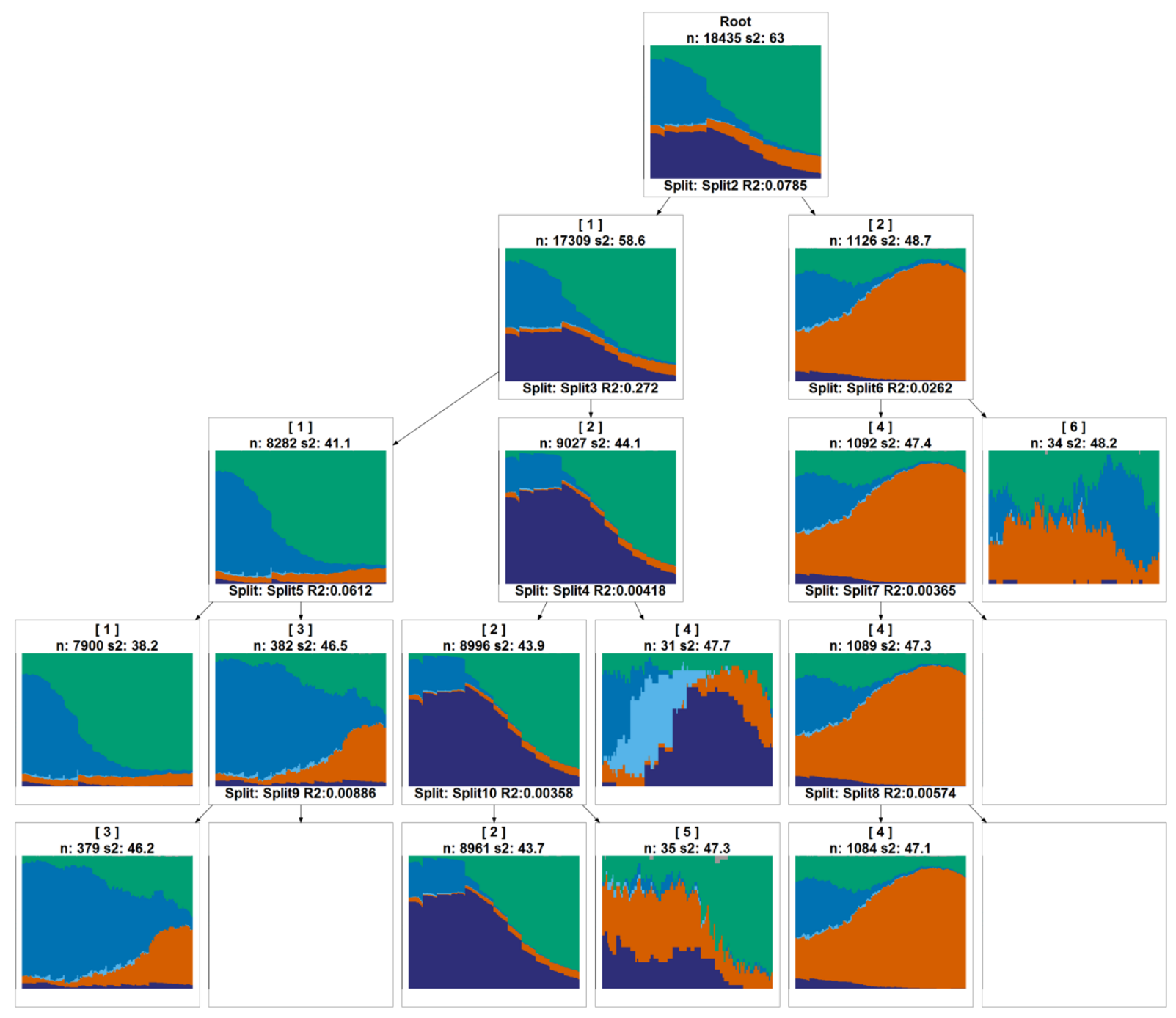

Appendix F: Sources of missing data

\begin{tabular}{lrr}
\hline Variable & Missing & \\
\hline single_parent & 2092 & 11.3 \\
female & $<10$ & \\
pared & 2419 & 13.1 \\
punemp & 3011 & 16.3 \\
hhincome_ssblk & 1804 & 9.8 \\
homeown & 1761 & 9.6 \\
educ & 36 & 0.2 \\
age & $<10$ & \\
emost & 3632 & 19.7 \\
extra & 3496 & 19 \\
consc & 3422 & 18.6 \\
agree & 3690 & 20 \\
auton & 3635 & 19.7 \\
gbageneratie & $<10$ & \\
rctot & 1150 & 6.2 \\
\hline
\end{tabular}


Appendix F: Cross tabulation of pupil's educational expectation and their educational track in 1999.

\begin{tabular}{lrrrr}
\hline \multirow{2}{*}{ Track in 1999 } & \multicolumn{4}{c}{ Pupil's educational expectation } \\
Academic & Vocational & Don't know & \multicolumn{1}{l}{ Total } \\
\hline \multirow{2}{*}{ General } & & & & \\
& 2,632 & 88 & 2,037 & 4,757 \\
& 55.33 & 1.85 & 42.8 & 100 \\
Vocational & & & & \\
& 1,787 & 1,243 & 3,166 & 6,196 \\
& 28.8 & 20.1 & 51.1 & 100 \\
\hline Total & 4,419 & 1,331 & 5,203 & 10,953 \\
& 40.35 & 12.15 & 47.5 & 100 \\
\hline
\end{tabular}

Appendix G: Cross tabulation of pupil's track before leaving school and their educational track in 1999.

\begin{tabular}{|c|c|c|c|}
\hline \multirow[b]{2}{*}{ Track before leaving school } & \multicolumn{3}{|c|}{ Track in 1999} \\
\hline & General & Vocational & Total \\
\hline \multirow{2}{*}{ Practical } & 99 & 618 & 717 \\
\hline & 13.81 & 86.19 & 100 \\
\hline \multirow[t]{2}{*}{ VMBO } & 439 & 3,624 & 4,063 \\
\hline & 10.8 & 89.2 & 100 \\
\hline \multirow[t]{2}{*}{ HAVO } & 1,961 & 986 & 2,947 \\
\hline & 66.54 & 33.46 & 100 \\
\hline \multirow[t]{2}{*}{ VWO } & 2,075 & 134 & 2,209 \\
\hline & 93.93 & 6.07 & 100 \\
\hline \multirow[t]{2}{*}{ Other (assigned) } & 183 & 834 & 1,017 \\
\hline & 17.99 & 82.01 & 100 \\
\hline \multirow[t]{2}{*}{ Total } & 4,757 & 6,196 & 10,953 \\
\hline & 43.43 & 56.57 & 100 \\
\hline
\end{tabular}

${ }^{\mathrm{i}}$ We have also used two other cost setting structures described by (Studer and Ritschard 2016): OMspell and SVRspell. Both do not give clear results as described in Table $\mathrm{X}$ in the appendix. 